\title{
Age Differences in LGBT Attitudes Toward Marriage Equality
}

\author{
Elaine M. Maccio \\ Sara Mateer DeRosa \\ Scott E. Wilks \\ Amy L. Wright
}

\begin{abstract}
The purpose of this study was to compare attitudes of older versus younger lesbian, gay, bisexual, and transgender (LGBT) individuals regarding marriage equality. Data were collected via self-report questionnaires from 350 LGBT adults in a mid-size city in the southern United States. Older and younger LGBT cohorts did not differ significantly in voter registration, political party affiliation, awareness of LGBT political issues, or voting on social issues. Older LGBT adults were less likely to find same-sex marriage important. Yet, age cohorts did not differ significantly on legalizing same-sex marriage. Social work implications are discussed regarding this policy area.
\end{abstract}

Keywords: LGBT, marriage equality, older adults, same-sex marriage, voting behavior

Lesbian, gay, bisexual, and transgender (LGBT) older adults in the United States are estimated to number between 1.75 million and 4 million (Administration on Aging, n.d.), a sizeable population to be sure. This subpopulation is rich in historical knowledge with increasing demand for awareness and training that targets this underserved subpopulation (Erdley, Anklam, \& Reardon, 2014). Scholarly literature on LGBT older adults is paltry; this lack of empirical data has been indicated as a crisis regarding sexual minority elders (Brown \& Grossman, 2014). Accordingly, few studies have investigated the LGBT and older adult social policy perspectives within this population.

Same-sex marriage, more recently referred to as marriage equality, emerged on the U.S. stage in 2003 when Massachusetts made history by becoming the first commonwealth in the nation to legalize same-sex marriage, with the first of those marriages taking place in 2004 (Goodridge v. Department of Public Health, 2003). However, the LGBT community is not of one mind on this issue (Lannutti, 2005). It is likely that views are split by, among other categories, age, much as ideas about heterosexual marriage are split along age lines in the heterosexual community (King \& Scott, 2005). Marriage is typically the domain of young adults (under the age of 35) for whom it often is a rite of passage, compared with middle-age and older adults who have likely already married at least once (Copen, Daniels, Vespa, \& Mosher, 2012). However, are we overlooking the importance that LGBT older adults place on marriage or, like their heterosexual counterparts, do LGBT older adults no longer consider it important, if they ever did? The purpose of this study is to compare the attitudes of older and younger LGBT cohorts regarding marriage equality.

\footnotetext{
Elaine M. Maccio, Ph.D., is an Associate Professor in the Louisiana State University School of Social Work; Sara Mateer DeRosa, MSW, is a Medical Social Worker at the Baton Rouge General Medical Center; Scott E. Wilks, Ph.D., LMSW, is a John A. Hartford Faculty Scholar in Geriatric Social Work and Associate Professor in the LSU School of Social Work; and Amy L. Wright, MSW, is a Ph.D. student in the LSU School of Social Work; all in Baton Rouge, LA.
} 


\section{Literature Review}

\section{History of Marriage Equality}

The struggle for marriage equality has been around since the early 1970s (Lewis \& Edelson, 2000), when at least three states, Minnesota, Kentucky, and Washington, heard cases on it. The argument was the same as it is today, challenging the limitation of marriage as only that between a man and a woman, and asking for equal protection under the $14^{\text {th }}$ Amendment of the U.S. Constitution (Lewis \& Edelson, 2000).

In 1993, the Hawaii Supreme Court heard the case of Baehr v. Lewin in which the plaintiff, suing the state for refusing to issue a marriage license to her and her same-sex partner, cited sex and sexual orientation discrimination (Lewis \& Edelson, 2000). After passing through the state supreme court, the trial court, and back, the Supreme Court of Hawaii determined that the state was within its rights to limit marriage to different-sex couples (Rimmerman, 2002). The year before the decision, the state legislature passed a constitutional amendment dictating the state's right to limit marriage to that between a man and a woman. According to Rimmerman (2002), although the law did allow domestic partnership benefits for same-sex couples, it strengthened the cause of those against marriage equality.

While the marriage debate raged on, states were, in one form or another, legalizing same-sex relationships. Hawaii was the first to legally recognize any kind of same-sex relationship (Stein, 2012) with its passage of the Reciprocal Beneficiaries Act in 1997 (Burnette, 1998-1999), which provided some of the benefits afforded to married couples. Vermont in 2000 was the first to legalize civil unions, and several other states followed suit (Stein, 2012).

During the 1990s, the United States saw further anti-gay and -lesbian legislation. The Defense of Marriage Act (DOMA), which defined marriage as the union of one man and one woman and exempted states from being forced to recognize same-sex marriages performed in other states (Defense of Marriage Act, 1996), was signed into law in 1996 by President Bill Clinton, despite his overwhelming support from the LGBT community in the 1992 presidential election (Lewis \& Edelson, 2000; Rimmerman, 2002). Following in the footsteps of Hawaii, over half of the United States enacted same-sex marriage limitations (Lewis \& Edelson, 2000). By 1998, 98\% of states had deliberated and $62 \%$ of states had approved measures barring same-sex marriage acknowledgment (HaiderMarkel, 2000). It was not until 1999 that the Vermont Supreme Court decided in Baker v. Vermont that the state legislature was allowed to make decisions about gay and lesbian rights under the law (Rimmerman, 2002), although it did not provide for the specific right of marriage. According to Rimmerman (2002), conservative organizations, in response, lobbied against same-sex marriage recognition in neighboring states, such as New Hampshire, and continued to work toward increasing the number of state bans.

As much of a setback as these bans were to LGBT civil rights, they also exacted a toll on LGBT individuals psychologically. LGBT people living in states with proposed ballot measures to ban same-sex marriage in 2006 experienced greater levels of psychological distress and minority stress than did LGBT people living in states with no such ballot measures (Rostosky, Riggle, Horne, \& Miller, 2009). Repeated exposure to negative media 
campaigns and the heated public debates that ensued left LGBT people in Colorado, Idaho, South Carolina, South Dakota, Tennessee, Virginia, and Wisconsin with greater negative affect and depressive symptoms.

\section{Current State of Marriage Equality}

As of May 2014, the District of Columbia and 18 states issued marriage licenses to same-sex couples (Human Rights Campaign [HRC], 2014a). In contrast, 28 states have constitutional amendments banning same-sex marriage, and four states have laws that restrict marriage to a man and a woman (HRC, 2014b). In a major victory for proponents of marriage equality, the U.S. Supreme Court on June 26, 2013, rendered DOMA unconstitutional (United States vs. Windsor, 2013).

\section{Same-Sex Marriage Statistics}

According to the U.S. Census Bureau, of the 116.7 million households in 2010 (Lofquist, Lugalia, O'Connell, \& Feliz, 2012), approximately $0.55 \%$ were married $(n=$ $131,729)$ or unmarried-partner $(n=514,735)$ households of same-sex couples (U.S. Census Bureau, 2011). Gates, Badgett, and Ho (2008) reported that over $40 \%$ of same-sex couples have participated in some type of state sanctioned relationship recognition. However, marriage appears to be the preferred form of recognition, as only $10-12 \%$ of same-sex couples sought domestic partnerships or civil unions in the first year they were available; while in the first year of marriage equality, over one third of gay and lesbian couples married in Massachusetts (Gates et al., 2008).

Also, using data from the American Community Survey, Gates et al. (2008) have shown that those seeking legal partnership status tend to be younger. This may be explained by the fact that LGBT older adults self-identified with the LGBT community later in life, while younger cohorts now self-identify as early as adolescence (Muraco, LeBlanc, \& Russell, 2008). That is, when they were younger, LGBT older adults had coupled with same-sex partners long before same-sex marriage was available and either are not motivated to legalize those relationships or are no longer in them. Other factors impacting marriage among LGBT older adults include the lack of role models within same-sex families during early development (Muraco et al., 2008).

\section{Attitudes}

Marriage equality has been a contentious issue in United States domestic policy since its inception. While its prominence in the media may suggest universal support among LGBT adults, attitudes differ. For example, lesbians and gay men with greater internalized homophobia, less education, and lower rates of disclosure to their families have less favorable attitudes toward same-sex marriage (Baiocco, Argalia, \& Laghi, 2014). Other studies have examined attitudes toward marriage equality based on whether or not an LGBT individual would marry if given the option. Using data from an online poll of LGBT adults (Egan \& Sherrill, 2005), approximately one quarter out of 748 participants who were surveyed would not choose to marry if it were legal.

According to the Services and Advocacy for Gay, Lesbian, Bisexual and Transgender Elders (SAGE) and the Movement Advancement Project (MAP), the lack of marriage 
equality has been identified as one challenge to healthy aging within the LGBT population (SAGE \& MAP, 2010). Specific obstacles include discrimination, legal inequalities, and dependence on chosen families, who are typically denied access to resources and privileges that legal and biological families are allowed (SAGE \& MAP, 2010).

In examining political participation and priorities, the Hunter College Poll (Egan, Edelman, \& Sherrill, 2008) revealed that protection from discrimination, both criminally and occupationally, was most important among those over age 65. Younger LGBT adults consider marriage equality and parental/adoption rights to be the two most important; these issues were ranked only fifth and seventh, respectively, within the older adult population (Egan et al., 2008). An earlier study (Egan \& Sherrill, 2005) suggested that differences between the older and younger LGBT cohorts may be explained by the fact that the younger generation is less tolerant of relationship discrimination and has higher expectations of equality. This leads us to ask, then, with the rapid and numerous changes in relationship recognition, at both the state and federal levels, over the past 6 years (since Egan et al.'s 2008 report), how does the issue of marriage equality, with its accompanying 1,138 benefits involving survivorship, taxation, retirement, and the like (Shah, 2004), look to LGBT older adults now?

\section{Methods}

\section{Design and Sampling}

This survey research utilized a cross-sectional design, which was appropriate for the purpose of gathering demographic and descriptive data from a localized population never before sampled for a quality-of-life study. Nonprobability sampling methods yielded 452 participants, 102 of whom were excluded for not meeting study eligibility requirements. Thus, a final sample of 350 participants was used in the analysis. The sample was primarily White $(84 \%)$, male $(50 \%)$, and gay $(47.1 \%)$, with a mean age of 37.1 years $(S D=13.16)$. Complete demographic data can be found in Table 1.

\section{Survey}

The 53-item, quantitative and short-answer survey ${ }^{1}$ was developed collaboratively by graduate students in a service-learning course on social work with LGBT people and the board of directors of a local LGBT advocacy organization. For the purpose of this study, we looked exclusively at the survey's two same-sex marriage items in regards to importance and legalization (e.g., "How important is it to you that same-sex marriage become legal in Louisiana?") and four of its political items in regards to voter registration, and political affiliation, influences, and awareness (e.g., "How aware are you of political issues and decisions regarding LGBT people?").

\footnotetext{
${ }^{1}$ This questionnaire can be made available to those who have interest in obtaining a copy by contacting the authors of this study.
} 
Table 1. Participant Demographics $(N=350)$

\begin{tabular}{|c|c|c|c|}
\hline Characteristic & $n$ & $\%$ & $M(S D)$ \\
\hline \multicolumn{4}{|l|}{ Race } \\
\hline European Amer./White & 294 & 84.0 & \\
\hline African Amer./Black & 28 & 8.0 & \\
\hline Hispanic/Latino & 7 & 2.0 & \\
\hline Biracial/Multiracial & 7 & 2.0 & \\
\hline Other & 14 & 4.1 & \\
\hline \multicolumn{4}{|l|}{ Gender } \\
\hline Male & 175 & 50.0 & \\
\hline Female & 165 & 47.1 & \\
\hline Transgender & 6 & 1.7 & \\
\hline Gender queer & 4 & 1.1 & \\
\hline Age (18-82 years) & & & $37.0(13.16)$ \\
\hline \multicolumn{4}{|l|}{ Sexual identity } \\
\hline Gay & 165 & 47.1 & \\
\hline Lesbian & 121 & 34.6 & \\
\hline Bisexual & 29 & 8.3 & \\
\hline Queer & 19 & 5.4 & \\
\hline Other & 16 & 4.6 & \\
\hline \multicolumn{4}{|l|}{ Education } \\
\hline High school/GED or less & 15 & 4.3 & \\
\hline Some college & 95 & 27.1 & \\
\hline Bachelor's degree & 100 & 28.6 & \\
\hline Some graduate & 41 & 11.7 & \\
\hline Graduate degree & 99 & 28.3 & \\
\hline \multicolumn{4}{|l|}{ Employment status } \\
\hline Employed full-time & 212 & 60.6 & \\
\hline Unemployed & 69 & 19.7 & \\
\hline Employed part-time & 31 & 8.9 & \\
\hline Student & 16 & 4.6 & \\
\hline Other & 21 & 6.0 & \\
\hline Missing/Invalid & 1 & 0.3 & \\
\hline Household income & & & $\$ 44,169(41,125.7)$ \\
\hline \multicolumn{4}{|l|}{ Relationship status } \\
\hline Partnered & 147 & 42.0 & \\
\hline Single & 179 & 51.1 & \\
\hline Married & 14 & 4.0 & \\
\hline Separated/div./widowed & 9 & 2.6 & \\
\hline Missing & 1 & 0.3 & \\
\hline
\end{tabular}




\section{Procedures}

The study was approved by the University's Institutional Review Board. LGBT individuals were invited to participate in a study on LGBT quality of life in a mid-size city in the Deep South. Individuals were eligible if they were at least 18 years of age and identified as LGBT or a related sexual identity (e.g., queer, questioning, same-sex attracted, etc.). They were excluded if they identified as heterosexual (and not also transgender) or acknowledged living outside the state. Participants living outside the metropolitan area but within the state were retained to provide a broader perspective of quality of life across the state. The survey was offered in electronic and hard-copy formats; however, all participants completed the survey online.

\section{Data Analysis}

Data were analyzed utilizing SPSS (version 21). Descriptive statistics were used to summarize sample characteristics. Chi-square was used for analyses with nominal and ordinal variables. To compare outcomes between younger versus older respondents, we dichotomized the sample according to age: those younger than 50 years $(78.9 \%)$, and those 50 years and older $(21.1 \%)$. Because of the small number of participants in the $50+$ age category, the response categories of some nominal and ordinal variables were collapsed.

\section{Results}

The overwhelming majority (92.3\%) of voting-eligible participants in the sample were registered voters, with more than half $(54.9 \%)$ identifying as Democrats. Nearly two thirds (64.9\%) reported being completely or somewhat aware of political issues and decisions affecting them as LGBT people. Participants' votes were influenced by social issues (74\%) far and above any other factor. Virtually all (95.4\%) agreed or strongly agreed that samesex marriage should be legal, and $79.4 \%$ felt it was very or somewhat important to them personally.

The sample was analyzed for its political involvement and awareness (see Table 2), providing a context for similarities and differences between the age cohorts on the politically charged issue of same-sex marriage. Younger and older LGBT cohorts did not differ in voter registration $\left(\chi^{2}=3.311, d f=1, p=.069\right)$, political party affiliation $\left(\chi^{2}=\right.$ $3.901, d f=3, p=.272$ ), awareness of political issues and decisions regarding LGBT people in the greater metropolitan area $\left(\chi^{2}=0.631, d f=2, p=.730\right)$, or voting on social issues $\left(\chi^{2}\right.$ $=2.018, d f=1, p=.155$ ).

Regarding the same-sex-marriage variables of interest (see Table 3), a chi-square test of independence found a significant difference between younger and older LGBT adults on the importance of same-sex marriage $\left(\chi^{2}=7.255, d f=2, p=.027\right)$. Standardized residuals revealed a higher-than-expected count of LGBT older adults who find same-sex marriage somewhat or very unimportant. However, the same test found no significant difference on allowing same-sex couples to enter a legal union offering the same benefits of marriage $\left(\chi^{2}=0.289, d f=2, p=.865\right)$. 
Table 2. Political Involvement and Awareness $(N=350)$

\begin{tabular}{lrr}
\hline Characteristic & $\boldsymbol{n}$ & $\boldsymbol{\%}$ \\
\hline Voter registration & & \\
Yes & 323 & 92.3 \\
No, eligible & 18 & 5.1 \\
No, not eligible & 8 & 2.3 \\
Not sure & 1 & 0.3 \\
Political party affiliation & & \\
Democrat & 192 & 54.9 \\
Independent & 67 & 19.1 \\
None & 38 & 10.9 \\
Republican & 24 & 6.9 \\
Libertarian & 13 & 3.7 \\
Other & 14 & 4.0 \\
Missing & 2 & 0.6 \\
Awareness of political issues and decisions regarding sexual orientation and gender identity \\
Completely unaware & 23 & 6.6 \\
Somewhat unaware & 63 & 18.0 \\
Neutral & 36 & 10.3 \\
Somewhat aware & 176 & 50.3 \\
Completely aware & 51 & 14.6 \\
Vote influencer & & \\
Social issues & 259 & 74.0 \\
Candidate & 192 & 54.9 \\
Economy & 175 & 50.0 \\
Political party & 111 & 31.7 \\
Environment & 92 & 26.3 \\
Race issues & 39 & 11.1 \\
Religious issues & 18 & 5.1 \\
\hline
\end{tabular}

\section{Discussion}

This study examined attitudes toward same-sex marriage among younger and older LGBT adults. Specifically, respondents were asked whether same-sex marriage should be legal and how important same-sex marriage was to them. The first question tapped into their global perceptions (i.e., should same-sex marriage be available in general), whereas the second question was more personal (i.e., does same-sex marriage matter to you personally). The issue of same-sex marriage is, among other things, a political one, so in order to gauge the nature of the sample's overall involvement in the political process and investment in political issues, responses to the same-sex marriage variables are presented against a backdrop of the sample's overall political awareness and involvement.

That LGBT younger adults bear no significant difference from LGBT older adults in voter registration, party affiliation, political awareness, and voting on social issues suggests that the cohorts are more similar than different. Statistically speaking, they are likeminded and relatively equally engaged and aware politically. 
Table 3. Attitudes Toward Marriage Equality $(N=350)$

\begin{tabular}{lrr}
\hline Characteristic & $\boldsymbol{n}$ & $\boldsymbol{\%}$ \\
\hline Importance of marriage equality & & \\
Very unimportant & 44 & 12.6 \\
Somewhat unimportant & 8 & 2.3 \\
Neutral & 18 & 5.1 \\
Somewhat important & 56 & 16.0 \\
Very important & 222 & 63.4 \\
Not sure & 1 & 0.3 \\
Missing & 1 & 0.3 \\
Same-sex marriage should be legal & & \\
Strongly disagree & 11 & 3.1 \\
Disagree & 0 & 0.0 \\
Neutral & 4 & 1.1 \\
Agree & 23 & 6.6 \\
Strongly agree & 311 & 88.9 \\
Missing & 1 & 0.3 \\
\hline
\end{tabular}

\section{Voter Registration}

A Gallup poll (Gates \& Newport, 2012) found that three quarters (74\%) of LGBT adults were registered to vote. Nearly all voting-eligible participants in the present study were registered to vote. Among them, similar rates of younger adults (93.7\%) and older adults $(98.6 \%)$ were registered to vote, whereas in the general population, $68.9 \%$ of younger adults (18-54 years) and $79.1 \%$ of older adults $(55+)$ were registered (Holder, 2006).

\section{Party Affiliation}

In singling out Democratic, Republican, and Independent participants, our sample was more Democratic (67.8\%) and less Republican (8.5\%) than Gallup's (Gates \& Newport, 2012) LGBT sample, which was $44 \%$ Democratic and $13 \%$ Republican. More than half (55\%) of 18-34-year-olds in the general population identified as Democrat, while $46 \%$ of those 35-64 and 48\% of those 65 and older did (Fisher, 2008). Fisher (2008) reported that individuals 35-64 identified themselves as Republican more (43\%) than any other age group; only $35 \%$ of those $18-34$ did so. Unlike heterosexuals, LGBT younger and older adults may unite on social issues, particularly those that affect them as LGBT people (e.g., adoption, parenting, marriage, etc.), and may therefore find themselves more often on the same side of the political aisle.

\section{Political Awareness}

LGBT younger adults (64.1\%) and their older counterparts (68.5\%) do not differ significantly in being somewhat or completely aware of political issues and decisions regarding LGBT people in the local area. In a study to determine the environmental factors that increase awareness of ballot propositions (i.e., political awareness), Nicholson (2003) reported civil liberties/rights as having the greatest impact, followed by media coverage. That virtually all LGBT political issues and decisions are about civil liberties and rights 
may explain, in part, the political awareness of nearly two thirds of our sample. There exist no empirical studies on the political awareness of LGBT individuals or of heterosexual individuals regarding LGBT issues.

\section{Social Issues Voting}

Researchers have noted voting influences ranging from voice pitch (Tigue, Borak, O'Connor, Schandl, \& Feinberg, 2012) to the economy (Pew Research Center, 2012). In our sample, no other issue came as close to influencing the vote of either age group as did social issues. Indeed, no other ballot measure is more motivating to any voter than one based on a social issue (Biggers, 2011). Social issues influenced the votes of LGBT younger adults (75.7\%) slightly more than they did older $(67.6 \%)$, although not significantly so. Votes influenced by the candidate came in a distant second among both younger $(54.3 \%)$ and older LGBT adults $(56.8 \%)$, and votes were least influenced by religious issues ( $5.4 \%$ younger adults, $4.1 \%$ older adults).

\section{Attitudes Toward Marriage Equality}

Legalization. As with Lannutti's (2005) mixed-age sample, the two LGBT age cohorts in the present sample agreed that same-sex couples should be allowed to be legally joined in a relationship that affords them the same rights, entitlements, and privileges as marriage, whatever it be called. However, whereas younger and older LGBT adults agree on legalizing same-sex marriage, younger and older heterosexual adults disagree. According to Masci (as cited in Becker \& Scheufele, 2011), $49 \%$ of young adults ( $<30$ years of age) favor same-sex marriage, whereas $65 \%$ of older adults $(\geq 65)$ oppose it. These findings were echoed by Becker (2012), who found Millennials (ages 18-29) most supportive of same-sex marriage and the Silent Generation $(65+)$ least supportive.

Perceived importance of marriage equality. Although they agreed on legalization, younger and older LGBT adults disagreed on the institution's importance. That is, older adults believe in legal recognition of relationships; they merely find that same-sex marriage is not for them. In fact, more older adults $(6.8 \%)$ in the sample were already married compared to their younger counterparts $(3.2 \%)$ and, coincidentally, more so to oppositesex partners $(60 \%)$ than younger adults were $(22.2 \%)$. More older adults $(2.6 \%)$ were also separated, divorced, or widowed than were younger adults (1.1\%). Similar to our sample, more older adults $(59.2 \%)$ in the general population are already married compared to their younger counterparts $(43.1 \%)$ and were also separated, divorced, or widowed $(33.7 \%)$ more than were younger adults (12.5\%; U.S. Census Bureau, n.d.).

In Lannutti's (2005) study of 288 LGBT individuals, younger participants recognized the importance of same-sex marriage as they grow older (e.g., making medical decisions, having access to a spouse's health insurance), but this apparently did not immediately resonate with older adults in the present study. This could possibly be due to a generational difference in life experiences. Indeed, children 10 years of age and younger have never been without marriage equality in at least one state in the U.S. Even adolescents are unlikely to remember the time before marriage equality in this country. To underscore the generational point, today's youth have very different expectations of themselves and others than did those before them (Marzullo \& Herdt, 2011). 


\section{Practice Considerations}

Our study revealed that although LGBT older adults support marriage equality on par with their younger counterparts, older adults find it not as important personally. Personal preference about marriage aside, the lack of marriage equality has a significant impact on LGBT older adults of which this population may be unaware. For example, among baby boomers, LGBT individuals are more likely to be caregivers than those in the general population, and gay and bisexual men are more likely to be caregivers than their heterosexual counterparts (MetLife, 2006). Fewer resources may be available to caregivers who are not married to their dependent partners, including the Family Medical Leave Act, which protects only those couples who are married (U.S. Department of Labor, n.d.).

Until President Obama urged the U.S. Department of Health and Human Services to initiate a policy to the contrary (Obama, 2010), hospitals across the country could deny visitation to individuals whose same-sex partners were hospitalized. The new policy, implemented in 2010, applies to hospitals that receive Medicare and Medicaid dollars, and although most do, some do not. Marriage equality would cover that gap, granting visitation to all couples regardless of the hospital's participation in federal funding programs.

In Stein and Bonuck's (2001) survey of 575 lesbian, gay, and bisexual people ranging in age from 19-83, 72\% reported familiarity with advance directives; however, only $38 \%$ had one. Even among LGBT older adults, most (72\%) had discussed advance directives with loved ones, but half (51\%) had not actually prepared one (MetLife, 2006). Without an advance directive, the default surrogate-selection policies in some states will overlook the same-sex partner of an incapacitated or deceased individual in favor of those next in line, such as biological relatives (Riggle, Rostosky, Prather, \& Hamrin, 2005).

Tax advantages and employee benefits (including death benefits) contribute to financial well-being among married partners, more so than among their unmarried counterparts; in turn, financial well-being becomes a significant contributor to physical and mental health (de Vries, 2007). However, without marriage, surviving partners are left with estate taxes and other financial penalties following their partner's death. Moreover, surviving partners of unmarried same-sex couples are denied their deceased partners' Social Security benefits (Sugarman, 2008).

Surviving partners may be prevented from claiming their deceased partner's remains and making funeral arrangements. This interferes with a critical component of grieving. For those LGBT older adults unable to marry their same-sex partners, this disenfranchised grief offers an additional layer of psychological distress uncommon among their heterosexual counterparts (McNutt \& Yakushko, 2013).

Practitioners working with LGBT older adults presenting with custodial, legal, end-oflife, and related concerns should assess clients' plans for themselves, their loved ones, and their estate in the event of their illness or death. It may be necessary to educate clients on their rights and responsibilities, rather than assume they already have this information, and present all available options for their consideration. Knochel (2010) recommends a reciprocal beneficiary agreement, which extends to unmarried partners some of the same rights afforded married couples, such as the right to make medical decisions on a partner's behalf and the right to inherit a deceased partner's estate. Until the issue of marriage 
equality is settled, practitioners must keep in mind the negative effect that anti-marriage equality campaigns and conversations can have on LGBT older adults (Rostosky et al., 2009). Negative reactions among LGBT individuals to these campaigns include fear, shock, and anger (Russell, 2000). Anti-gay politics, including said anti-marriage equality movements, contribute to a further deepening of disenfranchisement and psychological distress to this already marginalized group (LGBT older adults), which often leads to secrecy of loving, meaningful long-term relationships to avoid discrimination and ridicule (Butler, 2004).

The various types of difficulties and discrimination that can accompany the process of identifying as lesbian, gay, bisexual, or transgender often lead to psychosocial stressors within an individual's life. Given that a vast majority of LGBT individuals tend to seek out different forms of therapeutic treatment from mental health providers (Haas et al., 2011), it is imperative that social workers are equipped with adequate knowledge and training before clinically treating this population. Content focusing on LGBT individuals should be made mandatory within diversity and practice-related courses as opposed to solely within elective courses for social work students (Martin et al., 2009). Additionally, social work professionals should be responsible for commitment to attending annual, continuing education programs that contribute to their practice knowledge and sensitivity with LGBT issues (King, Semlyn, Killaspy, Nazareth, \& Osbom, 2007).

\section{Limitations}

A 2008 report by Egan et al. stated that $20 \%$ of the LGBT adult population was 55 and older. Our sample was slightly younger, with just 10.6\% 55 and older. While Egan et al. attribute the disproportionately low number to fewer LGBT older adults identifying as LGBT, we attribute our slim subsample to the potential inaccessibility of the online survey. As ubiquitous as computers have become, older adults lag behind younger age groups in access to and knowledge of computers (Shapira, Barak, \& Gal, 2007).

With limited age and race representation in our sample, the results are not generalizable beyond a small segment of a population - a segment that is primarily white, young, and middle-class - in a mid-size city in the Deep South. Inviting participants using language such as lesbian, gay, bisexual, and transgender may have overlooked individuals who do not use those terms to identify themselves, particularly older adults (Shankle, Maxwell, Katzman, \& Landers, 2003) and persons of color (Millett, Malebranche, Mason, \& Spikes, 2005). Additionally, many individuals within this population wish not to be aggregated as simply $L G B T$ and prefer to be understood within their respective orientations (e.g., transgender aging persons; Siverskog, 2014). Securing adequate sample sizes to address this issue is difficult but, nonetheless, important for future research.

Further, the lack of standardization regarding the present study's questionnaire is worth mentioning, as reliability and validity of the survey instrument are untested.

\section{Summary}

This study aimed to compare attitudes of older versus younger LGBT individuals regarding marriage equality. Older and younger LGBT cohorts did not significantly differ in voter registration, political party affiliation, awareness of LGBT political issues, or 
voting on social issues. Older LGBT adults were less likely to find same-sex marriage important. However, age cohorts did not differ significantly on marriage equality legalization. The future for social work researchers and practitioners working with older LGBT adults is looking brighter thanks to increased resources germane to this population, including the National Resource Center on LGBT Aging (see Meyer \& Johnston, 2014). We hope that, despite its limitations, this study adds to this brighter future by providing a snapshot of the marriage equality attitudes among younger and older LGBT adults. We believe that this study provides beneficial knowledge to social workers who practice with LGBT older adult clientele (individuals and families), and to social work educators who explore older, age-specific LGBT issues within their curricula.

\section{References}

Administration on Aging. (n.d.). Diversity. Retrieved from http://www.aoa.gov/AoA_programs/Tools Resources/diversity.aspx

Baiocco, R., Argalia, M., \& Laghi, F. (2014). The desire to marry and attitudes toward same-sex family legalisation in a sample of Italian lesbians and gay men. Journal of Family Issues, 35(2), 181-200. doi:10.1177/0192513X12464872

Becker, A. B. (2012). Determinants of public support for same-sex marriage:

Generational cohorts, social contact, and shifting attitudes. International Journal of Public Opinion Research, 24(4), 524-533.

Becker, A. B., \& Scheufele, D. A. (2011). New voters, new outlook? Predispositions, social networks, and the changing politics of gay civil rights. Social Science Quarterly, 92(2), 324-345.

Biggers, D. (2011). When ballot issues matter: Social issue ballot measures and their impact on turnout. Political Behavior, 33(1), 3-25.

Brown, M. T., \& Grossman, B. R. (2014). Same-sex sexual relationships in the national social life, health and aging project: Making a case for data collection. Journal of Gerontological Social Work, 57, 108-129. doi:10.1080/01634372.2013.865695

Burnette, W. B. (1998-1999). Note: Hawaii's Reciprocal Beneficiaries Act: An effective step in resolving the controversy surrounding same sex marriage. Brandeis Law Journal, 37, 81-95.

Butler, S. S. (2004). Gay, lesbian, bisexual, and transgender elders: The challenges and resilience of this marginalized group. Journal of Human Behavior in the Social Environment, 9(4), 25-44.

Copen, C. E., Daniels, K., Vespa, J., \& Mosher, W. D. (2012). First marriages in the United States: Data from the 2006-2010 National Survey of Family Growth. Retrieved from the Centers for Disease Control and Prevention website: http://www.cdc.gov/nchs/data/nhsr/nhsr049.pdf

Defense of Marriage Act of 1996. 28 U.S.C. $\S 1738 C$ et seq. Retrieved from the U.S. Government Printing Office website: http://www.gpo.gov/fdsys/pkg/BILLS104hr3396enr/pdf/BILLS-104hr3396enr.pdf 
de Vries, B. (2007). LGBT couples in later life: A study in diversity. Generations, 31(3), 18-23.

Egan, P. J., Edelman, M. S., \& Sherrill, K. (2008). Findings from the Hunter College poll: New discoveries about the political attitudes of lesbians, gays and bisexuals. Retrieved from http://as.nyu.edu/docs/IO/4819/hunter college poll.pdf

Egan, P. J., \& Sherrill, K. (2005). Marriage and the shifting priorities of a new generation of lesbians and gays. PS: Political Science \& Politics, 38, 229-232.

Erdley, S. D., Anklam, D. D., \& Reardon, C. C. (2014). Breaking barriers and building bridges: Understanding the pervasive needs of older LGBT adults and the value of social work in health care. Journal of Gerontological Social Work, 57, 362-385. doi:10.1080/01634372.2013.871381

Fisher, P. (2008). Is there an emerging age gap in US politics? Society, 45(6), 504-511.

Gates, G. J., Badgett, M. V. L., \& Ho, D. (2008). Marriage, registration and dissolution by same-sex couples in the U.S. Retrieved from http://williamsinstitute.law.ucla.edu/wp-content/uploads/Gates-Badgett-Ho-CouplesMarr-Regis-Dissolution-Jul-2008.pdf

Gates, G. J., \& Newport, F. (2012). LGBT Americans skew Democratic, largely support Obama. Retrieved from the Gallup Politics website: http://www.gallup.com/poll/158102/lgbt-americans-skew-democratic-largelysupport-obama.aspx

Goodridge v. Department of Public Health. 798 N.E.2d 941 (Mass. 2003). Retrieved from the Columbia Law School website:

http://www2.law.columbia.edu/faculty_franke/Gay_Marriage/Goodridge\%20Decisio n\%20edited\%20Fundamental\%20Right.pdf

Haas, P., Eliason, M., Mays, V. M., Mathy, R. M., Cochrain, S. D., D’Augelli, A. R.,...Clayton, P. J. (2011). Suicide and suicide risk in lesbian, gay, bisexual and transgender populations: Review and recommendations. Journal of Homosexuality, 58(1), 10-51.

Haider-Markel, D. P. (2000). Lesbian and gay politics in the states: Interest groups, electoral politics and policy. In C. Rimmerman, K. D. Wald, \& C. Wilcox (Eds.), The politics of gay rights (pp. 290-346). Chicago, IL: The University of Chicago Press.

Holder, K. (2006). Voting and registration in the election of November 2004 (Report No. P20-556). Retrieved from the U.S. Census Bureau website: http://www.census.gov/prod/2006pubs/p20-556.pdf

Human Rights Campaign [HRC]. (2014a). Marriage equality and other relationship recognition laws. Retrieved from http://hrc-assets.s3-website-us-east1.amazonaws.com//files/assets/resources/marriage-equality_5-2014.pdf

HRC. (2014b). Statewide marriage prohibitions. Retrieved from http://www.hrc.org/resources/entry/maps-of-state-laws-policies 
King, M., Semlyn, J., Killaspy, H., Nazareth, I., \& Osbom, D. (2007). A systematic review of research on counseling and psychotherapy for lesbian, gay, bisexual and transgender people. Retrieved from http://www.nitherapy.net/assets/images/2012/05/BACP LGBTreview.pdf

King, V., \& Scott, M. E. (2005). A comparison of cohabiting relationships among older and younger adults. Journal of Marriage and Family, 67(2), 271-285.

Knochel, K. (2010). Marriage, civil unions, or reciprocal beneficiary agreements: What best protects older LGBT people? Journal of Gay \& Lesbian Social Services, 22(1/2), 22-39.

Lannutti, P. J. (2005). For better or worse: Exploring the meanings of same-sex marriage within the lesbian, gay, bisexual and transgendered community. Journal of Social and Personal Relationships, 22(1), 5-18.

Lewis, G. B., \& Edelson, J. L. (2000) DOMA and ENDA: Congress votes on gay rights. In C. Rimmerman, K. D. Wald, \& C. Wilcox (Eds.), The politics of gay rights (pp. 193-216). Chicago, IL: The University of Chicago Press.

Lofquist, D., Lugalia, T., O’Connell, M., \& Feliz, S. (2012). Households and families: 2010. Retrieved from U.S. Census Bureau website: http://www.census.gov/prod/cen2010/briefs/c2010br-14.pdf

Martin, J. I., Messinger, L., Kull, R., Holmes, J., Bermudez, F., \& Sommer, S. (2009). Council on Social Work Education - Lambda Legal study of LGBT issues in social work. Retrieved from http://www.cswe.org/File.aspx?id=25678

Marzullo, M. A., \& Herdt, G. (2011). Marriage rights and LGBTQ youth: The present and future impact of sexuality policy changes. Ethos, 39(4), 526-552.

McNutt, B., \& Yakushko, O. (2013). Disenfranchised grief among lesbian and gay individuals. Journal of LGBT Issues in Counseling, 7(1), 87-116. doi:10.1080/15538605.2013.758345

MetLife. (2006). Out and aging: The MetLife study of lesbian and gay baby boomers. Retrieved from https://www.metlife.com/assets/cao/mmi/publications/studies/mmiout-aging-lesbian-gay-retirement.pdf

Meyer, H., \& Johnston, T. R. (2014). The National Resource Center on LGBT Aging provides critical training to aging service providers. Journal of Gerontological Social Work, 57, 407-412. doi:10.1080/01634372.2014.901997

Millett, G., Malebranche, D., Mason, B., \& Spikes, P. (2005). Focusing "down low": Bisexual black men, HIV risk and heterosexual transmission. Journal of the National Medical Association, 97(7), 52S-59S.

Muraco, A., LeBlanc, A. J., \& Russell, S. T. (2008). Conceptualizations of family by older gay men. Journal of Gay \& Lesbian Social Services, 20, 69-90. doi:10.1080/10528720802178957

Nicholson, S. P. (2003). The political environment and ballot proposition awareness. American Journal of Political Science, 47(3), 403-410. 
Obama, B. (2010). Presidential memorandum: Hospital visitation. Retrieved from the White House website: http://www.whitehouse.gov/the-press-office/presidentialmemorandum-hospital-visitation

Pew Research Center. (2012). Energy, terrorism, immigration less important than in 2008. Retrieved from http://www.people-press.org/files/legacy-pdf/9-2412\%20Voters $\% 20$ Priorities\%20Release.pdf

Riggle, E. D. B., Rostosky, S. S., Prather, R. A., \& Hamrin, R. (2005). The execution of legal documents by sexual minority individuals. Psychology, Public Policy, and Law, 11(1), 138-163.

Rimmerman, C. A. (2002). From identity to politics: The lesbian and gay movements in the United States. Philadelphia, PA: Temple University Press.

Rostosky, S. S., Riggle, E. D. B., Horne, S. G., \& Miller, A. D. (2009). Marriage amendments and psychological distress in lesbian, gay, and bisexual (LGB) adults. Journal of Counseling Psychology, 56(1), 56-66.

Russell, G. M. (2000). Voted out: The psychological consequences of anti-gay politics. New York, NY: New York University Press.

Services and Advocacy for Gay, Lesbian, Bisexual and Transgender Elders \& Movement Advancement Project [SAGE \& MAP]. (2010). Improving the lives of LGBT older adults. Retrieved from http://www.lgbtmap.org/file/improving-the-lives-of-lgbtolder-adults.pdf

Shah, D. (2004, January 23). [Letter to the Honorable Bill Frist]. Retrieved from the General Accounting Office website: http://www.gao.gov/new.items/d04353r.pdf

Shankle, M. D., Maxwell, C. A., Katzman, C. S., \& Landers, S. (2003). An invisible population: Older lesbian, gay, bisexual, and transgender individuals. Clinical Research and Regulatory Affairs, 20, 159-182.

Shapira, N., Barak, A., \& Gal, I. (2007). Promoting older adults' well-being through Internet training and use. Aging \& Mental Health, 11, 477-484.

Siverskog, A. (2014). "They just don't have a clue": Transgender aging and implications for social work. Journal of Gerontological Social Work, 57, 386-406. doi:10.1080/01634372.2014.895472

Stein, E. (2012). The topography of legal recognition of same-sex relationships. Family Court Review, 50(2), 181-204.

Stein, G. L., \& Bonuck, K. A. (2001). Physician-patient relationships among the lesbian and gay community. Journal of the Gay and Lesbian Medical Association, 5(3), 8793.

Sugarman, S. D. (2008). What is a family-Conflicting messages from our public programs. Family Law Quarterly, 42(2), 231-261.

Tigue, C. C., Borak, D. J., O'Connor, J. J. M., Schandl, C., \& Feinberg, D. R. (2012). Voice pitch influences voting behavior. Evolution and Human Behavior, 33(3), 210216. 
United States vs. Windsor, 570 U.S. (2013). Retrieved from http://www.supremecourt.gov/opinions/12pdf/12-307_6j37.pdf

U.S. Census Bureau. (2011). Census Bureau releases estimates of same-sex married couples. Retrieved from http://www.census.gov/newsroom/releases/archives/2010 census/cb11-cn181.html

U.S. Census Bureau. (n.d.). Marital status: 2012 American Community Survey 1-year estimates. Retrieved from http://factfinder2.census.gov/faces/tableservices/jsf/pages/productview.xhtml?pid=A CS_12_1YR_S1201\&prodType $=$ table

U.S. Department of Labor. (n.d.). The Family and Medical Leave Act of 1993, as amended. Retrieved from http://www.dol.gov/whd/fmla/fmlaAmended.htm

\section{Author note}

Address correspondence to: Scott E. Wilks, PhD, LMSW, John A. Hartford Faculty Scholar in Geriatric Social Work and Associate Professor, Louisiana State University School of Social Work, 307 Huey P. Long Field House, Baton Rouge, LA 70803. Email: swilks@1su.edu 